\title{
The Role Of Sismiop (Information Management System Of Tax Object) In Land And Building Tax Revenues (A Case Study At The Regional Revenue Agency, Medan)
}

\author{
Farel Siregar \\ Department of Management \\ University of Sumatera Utara \\ Medan, Indonesia \\ farelsir@gmail.com
}

\begin{abstract}
The gap between NJOP (Tax Object Sales Value) of land, issued by the Regional Revenue Agency, Medan, and market value of each tax object today is worthwhile to be analyzed. The objective of the research was to find out to analyze whether some factors such as land area, road width, and location had the significant influence on land value simultaneously.

The data were analyzed by using multiple linear regression analysis and by conducting observation. The samples were taken by using simple random sampling technique by numbering each population unit and drawing them randomly. Slovin formula was used to find out the number of samples. There were 100 samples which were mostly distributed in 6 kelurahan (villages): Kelurahan Suka Maju, Kelurahan Titi Kuning, Kelurahan Kedai Durian, Kelurahan Pangkalan Masyhur, Kelurahan Gedung Johor, and Kelurahan Kwala Bekala which was located in Medan Johor Sub-district.

The result of the research showed that at $\alpha=5 \%$, the variable of land area had the negative but significant influence on land value and the variable of road width had the positive and significant influence on land value. Meanwhile, the variable of location did not have any significant influence on land value. The conclusion was that independent variables of land area, road width, and location simultaneously could explain the changes in dependent variable of land value.
\end{abstract}

Keywords: NJOP of Land; Market Value; Land Area; Road Width; Location

\section{INTRODUCTION}

\subsection{Background Research}

The objective of SISMIOP (Information Management System of Tax Object) is based on the Decree of Directorate General of Tax No. KEP-533/PJ/2000 is to establish or to maintain data basis (through registration, data completion, and valuation) by using computer which functions to create an accurate and up to date data basis by integrating all administrative activities of PBB (Land and Building Tax) in one place, so that its implementation can have more conformity, be simpler, faster and more efficient. Therefore, it is expected that it can make tax imposition more fair and equal, increase potential realization/main provisions, improve administrative conformity, raise $\mathrm{PBB}$ revenues, and provide better service to tax payers. It is important to have good maintenance of data basis to keep the data accuracy of tax subject and object so that they are relevant, punctual, accountable, and up to date (Wahyudi H, 2014) [1]. However, in reality, SISMIOP that has been implemented is considered expired, especially in the valuation system of tax object because practically, the implementation of the system, in fact, decrease the realization of PBB tax collection in subdistricts. Consequently, the target of tax revenue is not achieved which is applied so far is considered to have expired (Head of Subdistrict Complained the data of Tax Payers: Seputar Indonesia Daily, 2009) [2].

According to the author's observation and experience who has been dealing with NJOP PBB valuation for more than five years, people's complaints about NJOP are mostly caused by two things. Firstly, the nature of tax payers who want to pay as low tax as possible and if possible they want to avoid tax payment. Secondly, taxpayers feel that NJOP that is determined is not accurate because they still find errors in its fiscal valuation or the limited information regarding tax determination that has created the perception to people whose property value is lower that the determined NJOP

Among all problems discussed above, this research is focused on the factors that influence land value, on the analysis of these factors, such as land area, location, and road width; in which valuation id one of the elements in SISMIOP.

\subsection{Problem Formulation}

Based on the aforementioned background, there are several essential problems to be solved by this research; namely, whether the land area, road width, and location simultaneously have the significant influence on the determination of NJOP of land in Medan Johor Sub district, Medan.

\subsection{Research Objective}

The objective of the research was to discover whether the factors that influence land value, such as land area, road width and location simultaneously have the significant influence on 
the market value of land in the determination of Land NJOP in Medan Johor Sub district, Medan.

\subsection{Research Significance}

This research is aimed at providing some inputs to Regional Revenue Agency of Medan as an agency that manages PBB since January 1, 2017, so that it can make a review to increase the tax revenue through SISMIOP.

\section{LIBRARY REVIEW}

\section{A. Division of Tax}

Waluyo (2011) states that taxes are dues to the (that can be imposed) state owed by those obliged to pay according to the regulations, without recast achievement, which can be directly demonstrated and the point is to finance general expenses related to the task of the state that organizes the government. Meanwhile, according to Soemitro in Mardiasmo (2011), Tax is a contribution of the people to the State treasury under the law (which can be imposed) by not getting lead services (contra-achievement), which can be directly shown and used to pay public expenditure. This formulation further emphasizes the budgetary function of the tax that is how the tax revenue is used to fill the state treasury. Apart from taxes, state revenue can also be obtained from levies, donations, duties and stamp duties, domestic and foreign loans, income from state enterprises or money-making (Darwin, 2013) [3].

From a fiscal point of view, the tax is the state revenue used to improve the welfare of the people with the basic principles of collecting funds obtained from and for the society through mechanisms that refer to the prevailing laws and regulations (Chaizi, 2013).

\section{SISMIOP (Information Management System of Tax Object)}

Widodo (2010) [4], states that SISMIOP is an itegrated system to process the information/data of the object and subject of PBB (Land and Building Tax) by using computer started from data collection (through registration, data completion and valuation), provision of tax payer's identitification i.e. NOP (Tax Object Number), data recroding, data basis maintenance, output printing (such as SPPT, STTS, DHKP, etc.), revenue supervision and implementation of tax billing, until the service to tax payers through One Stop Service.

The indicator of SISMIOP consists of some steps; Namely, Registration, Data Completion, and Valuation. The indicator emphasized in this research is the valuation which often becomes the problem in tax revenues.

\section{B. Definitions of Value and Price}

Values under the Indonesian Appraisal Code of Ethics and the Indonesian Values Standards (KEPI \& SPI Edition VI2015) [5] are an opinion of the economic benefits of asset ownership, or the price most likely to be paid for an asset in exchange, so the value is not a fact. Assets are also defined as goods and services. The value in exchange is a hypothetical price of the value estimated and determined by a valuation at a given time. To the owner, a value is an estimate of the benefits that a particular party will gain over ownership.

The definition of price according to Indonesian Appraisal Code of Ethics and Indonesian Valuation Standards (KEPI \& SPI Edition VI-2015) is the amount of money demanded, offered or paid for an asset. Due to the financial ability, motivation or special interests of the buyer or seller, the price paid may differ from the value of the asset based on the other party's assumption.

The concept of market value should not depend on the actual transaction that occurred on the valuation date. Market Value is more an estimate of the price that may occur in the sale on the date of valuation by the requirements of the definition of market value. The market value is a representation of the price agreed upon by the buyer and the seller at that time according to the definition of market value; previously each party has had enough time to test the possibilities and other opportunities and realize that it will likely take time to prepare a formal contract and other documentation.

\section{Factors that Influence Land Value}

\section{Land Area}

Various researches and empirical studies of property values reveal that the variables that make up the value of a property include the physical characteristics of the real estate concerned, the economic, political, social and legal conditions about the right to the property, which can generally be categorized as follows (Sidik, 2000):

a) Physical attributes include the quantitative characteristics of the housing such as building area, land area, number of rooms, building facilities and number of the bathroom; and the qualitative characteristics of the housing such as space conditions, environmental comfort.

b) The location includes the influence of government fiscal policies and transport fee to the city center.

c) Economic externalities include air quality, ethnical group, and public facilities such as the park.

d) A financial institution includes the kinds and conditions of housing sector loan, subsidy, and loan availability.

e) Transaction fee that influences the market price of the financial sector.

Edy Siswanto (2006) [6] in his research entitled "Analysis of the Influence of Distance, Width of the Road, and Land Area for Determination of NJOP of Land (A Case Study in Sukagalih Sub-District, Bandung)" found that the variables such as distance, width of road and land area significantly influenced the value of land for the determination of NJOP of Land.

\section{Road Width}

Road width is the width of the road in front of the land and the building which becomes the main access to the location of the land and the building and is calculated in meters (m). 
Irawan and Pranata (2010) state that road width in front of the land has a positive and significant influence on the value of the land. Meanwhile, Sutawijaya (2004) discovered that the width of the road in front of the land would have a positive influence on land value by $0.402 \%$. While Edy Siswanto (2006) in his research entitled "Analysis of the Influence of Distance, Width of the Road, and Land Area for Determination of NJOP of Land (A Case Study in Sukagalih Urban Village Bandung)" found that distance, width of road and land area significantly influenced the value of land for the determination of NJOP of Land.

\section{Location}

Location is an important factor that influences the value of property. Location problems are related to accessibility measured by the convenience of a particular center and environmental conditions related to the circumstances surrounding the field/ site. The difference in land prices according to Woolery occurs due to location differences (Nasucha, 1995). This is in line with the theory of regional economic approaches that define optimal location will generate optimal profit for the seller because of the availability of facilities and infrastructure so that the location of the land greatly influences the value of property.

4. Relationship between Management Information System of Tax Objects and Land and Building Tax Revenues

Sony Devano and Siti Kurnia Rahayu (2006) mentioned that factors affecting tax revenues are the clarity and certainty of tax laws and regulations, the intellectual level of society, the quality of the tax officer (intellectual, skill, integrity and high moral), and the right tax administration system. Widodo (2010) argues that there are several supporting applications in SISMIOP application, which is an integrated information system with all UN activities in the form of Geographic Information System (GIS), Payment Online System (POS) and Telephone Information Service (PIT) which goal to be achieved by this system is to improve services to WP by way of providing the opportunity to pay PBB at any Paying Bank (TP), to improve the performance of Paying Bank in providing services to WP and to minimize manipulation, provide accurate data at all times to interested parties, and increase the revenue of the Regional Government in particular and the State in general.

\section{Previous Researches}

Researches on the influence and role of SISMIOP of land and building have been done in Indonesia. One of them Susanto (2015) who researched the value of land as the basic Value of Object Tax (NJOP) of Land according to economic and environmental aspects. This study was conducted in Sewon District, Bantul Regency. Indicators used in this research are the main road network, activity center (Central Business District), land use, environmental carrying capacity (DDL), compatibility of land typology using Hierarchical Clustering method with firstly weighted by Analytic Hierarchy Process (AHP) and Scaling. Preparation of land value is based on land typology. The classification of land values is formulated by hierarchical formulations. The results showed that Sewon sub-district could be categorized into four types. Type I is land with the low land economic condition and low environmental condition; Type II with the medium economic condition of medium land and medium environmental condition; Type III with high land economic conditions and medium environmental conditions; and Type IV with poor (low) land economic conditions and high environmental conditions. Type of land with poor (low) environmental conditions gets major attention in environmental improvement. Recommendations compiled are Land, and Building Taxes may be a disincentive for improving adverse environmental conditions in the region.

Fajarhayu, et al. (2015) [7] researches the analysis of the level of regional income in determining the NJOP of Land. This research was conducted in Sumberrejo Sub-district, Bojonegoro District. This is a descriptive research with quantitative approach. This study aims to measure the accuracy of the determination of NJOP of Land by the Regional Revenue Service of Bojonegoro Regency in Sumberrejo Sub District in 2014. Based on the research, it was found out that the determination of NJOP of Land in Sumberrejo Sub-district was relatively accurate but lacked conformity, so it needs to be re-appraisal.

\section{RESEARCH CONCEPT FRAMEWORK}

From some theories about land values, in general, the theory suggests that there is a close relationship between land area, location, and road width to the value of land. The difference in land value is due to the difference in the attractiveness of a location. In general there are two kinds of attraction of a location i.e. it is easy to reach workplace, shopping centers, health centers, school, recreation, worship and other locations that require travel and the state of physical and social environment such as topography, cleanliness of water, air and comfort (Nasucha, 1995).

\section{A. Thought Framework}

Based on the theories of previous valuation and research that have been described, the schematic conceptual framework of research to be conducted in this study is described in Figure 1 as follows:

Figure 1. Research Concept Framework

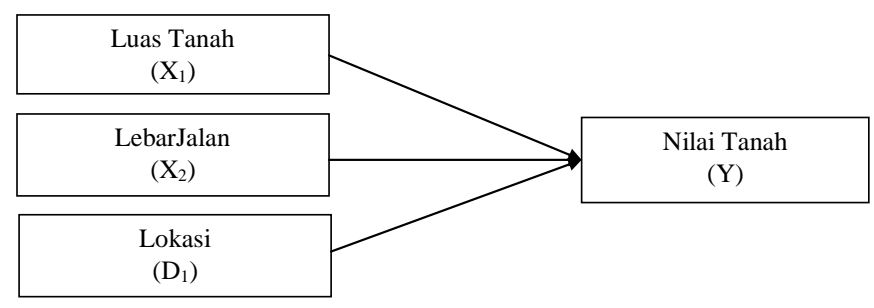

Theoretical Thinking Framework above explains that the Land Value (Y) is influenced by land area (X1), the width of the road (X2) and location (D1). The figure above also explains that the arrows from the left of the right are a figure 
of the influence between land width variables, road width, and location as dummy free variable to the value of the soil.

\section{B. Hypothesis}

Based on the background and purpose of the study, as well as the description of previous research and theoretical framework, this research proposes some hypothesis as follows

- Land Area Factor had the positive and significant influence on land value.

- Road Width Factor had the positive and significant influence on land value.

- Location factor had the positive and significant influence on land value.

\section{RESEARCH METHOD}

This is a quantitative research, which phenomena can be categorized, relatively fixed, observable, measurable and has causal symptoms. Hypotheses were tested through data collection. The collected data were analyzed using statistics and econometrics, so it can be concluded that the hypotheses that have been formulated can be proved or not (Sugiono, 2012) [8].

Statistics used in this study are inferencing statistics. Inferencing statistics are the statistics that studies how to conclude the entire population based on sampled data. Meanwhile, the meaning of econometrics is the partial quantitative analysis of real economic phenomena based on the development of theory and observation associated with inference method (Suliyanto, 2011).

The population in this study is all NJOP of the Land from the Taxpayer (WP) determined and issued by the Regional Revenue Agency of Medan and all areas of land located in Medan Johor Subdistrict covering Suka Maju Subdistrict, Titi Kuning Village, Kedai Durian Village, Pangkalan Mashyur Sub-district, Gedung Johor Village, and Kwala Bekala Village. The stages in the sampling design process consist of 1) defining the target population, 2) determining the sample frame, and 3) determining the number of samples and simultaneously determining how to draw the sample members (Fachrudin and Meliza, 2014) [9].

The analytical tool used in this research was multiple linear regression analysis, i.e., regression analysis which explains the relationship between the changes of response (dependent variable) with factors that influence more than one predictor (independent variable). Multiple linear regression is almost the same as simple linear regression; only in multiple linear regression, independent variable more than one variable estimator. The purpose of multiple linear regression analysis is to measure the intensity of the relationship between two or more variables and to make an approximate prediction of the $\mathrm{Y}$ value over $\mathrm{X}$.

Multiple linear regression model was employed in this research for the population as follows:

$$
\mathrm{Y}=\alpha+\beta_{1} \mathrm{X}_{1}+\beta_{2} \mathrm{X}_{2}+\beta_{3} \mathrm{D}_{1}+\varepsilon
$$

$\mathrm{Y} \quad=$

$\alpha=$

$\beta_{1} \quad=$

$\beta_{2}=$

$\beta_{3}=$

$\mathrm{X}_{1}=$

$\mathrm{X}_{2} \quad=$

$\mathrm{D}_{1} \quad=$

$\varepsilon \quad=$

Land Value (rupiah/m²)

constanta (intercept)

coeficient of land area

coeficient road width

dummy coeficient of land location

land area in meter

road width in meter

dummy variable of land location (main street/in avenue), 1 if it is on main street

, 0 if it is located in an avenue

residual value (bothering value)

Classic assumption testing is needed to determine whether the regression estimation results are completely free from symptoms of heteroscedasticity, multicollinearity, and autocorrelation. The regression model can be used as an unbiased estimator if it meets the requirements of BLUE (Best Linear Unbiased Estimator), i.e., there is no heteroscedasticity, multicollinearity, and autocorrelation (Sudrajat, 1998).

If there is heteroscedasticity, the variant is not constant so it can cause a standard deviation. If there is multicollinearity, it will be difficult to isolate the individual effects of the variables, so that the significance level of the regression coefficients becomes low. With autocorrelation, the estimator remains deviated and remains consistent, yet inefficient. Therefore, the classical assumption test needs to be done.

\section{a) Normality Test}

The normality test aims to find out whether in the regression model the intruder or residual variable has a normal distribution (Erlina, 2008). Good data is data that has a belllike pattern on the histogram diagram. Normality test data used in this study is Kolmogorov-Smirnov Test. The criteria for testing one sample using a one-sided test is to compare probability with a certain level of significance that is if the value is significant or probability $<0.05$, then the data distribution is abnormal and if significant value or probability $>0.05$, then the data is normally distributed (Ghozali, 2006) [10].

\section{b) Multi-co-linearity Test}

Multicollinearity test aims to test whether there was any correlation among independent variables (independent) in the regression model. A good regression model should not have any correlation among independent variables. Multicollinearity test is done by observing the tolerance and variance inflation factor (VIF) from the analysis result using SPSS. If the tolerance value is higher than 0.10 or VIF is smaller than ten then it can be concluded that there is no multicollinearity (Santoso, 2002).

c) Heteroscedasticity Test

Heteroscedasticity test aims at testing whether there are any variance and the residual difference between one 
observation and another one in the regression model. If the variance and residual of one observation are similar to the other observation is the same, it is called Homoscedasticity; and if they are different from one another, it is called heteroscedasticity. A good regression model showed homoscedasticity instead of heteroscedasticity.

\section{d) Goodness of Fit Test}

To see the goodness of fit model, the important one to observe $\mathrm{F}$ test, $\mathrm{t}$-test, dan $\mathrm{R}^{2}$ (Fachruddin, Khaira Amalia dan Juli Meliza, 2014). In this research, $F_{\text {-test }}$ will be compared with $\mathrm{F}_{\text {-table }}$ 5\%. Assesment hypothesis criteria on this F-test is :

To observe the goodness of fit model, what needs to be considered are $\mathrm{F}$ test, t-test, and $\mathrm{R}^{2}$ (Fachruddin, Khaira Amalia and July Meliza, 2014). In this study, F count value will be compared with $\mathrm{F}$ table $5 \%$. The criteria of hypothesis valuation in this $\mathrm{F}$ test are:

$\mathrm{H}_{\mathrm{o}}$ is not rejected if: count $\leq \mathrm{F}_{\text {table }}$

$\mathrm{H}_{\mathrm{o}}$ is rejected if $\mathrm{F}_{\text {count }}>\mathrm{F}_{\text {table }}$

This research compares $t$-count with $t$-table on the significance level 5\%. The criteria for hypothesis valuation in t-test are:

$\mathrm{H} 0$ is not rejected if $-\mathrm{t}$ table $\leq \mathrm{t}$ count $\leq \mathrm{t}$ table

$\mathrm{H} 0$ is rejected if $\mathrm{t}$ count $>\mathrm{t}$ table or $-\mathrm{t}$ count $\leq-\mathrm{t}$ table

For the purpose to make it easier, the $p$ value can be seen from the results of data analysis. If it is lower than the alpha used, it means that $\mathrm{H} 0$ is rejected or in other words, $\mathrm{H} 1$ is accepted which indicates that there is a significant influence.

\section{e) Determination Test $\left(R^{2}\right)$}

Determination test is conducted to measure how far the ability of variation of the free variable is in explaining the variation of dependent variables (Fachruddin, Khaira Amalia and July Meliza, 2014). When using correlation, the hypothesis is as follows: $\mathrm{H} 0: \mu 1=\mu 2$ or $\mathrm{H} 1: \mu 1 \neq \mu 2$. If the value of the $p$ value of the data analysis result is lower than the alpha used, then $\mathrm{H} 0$ is rejected, or in other words, $\mathrm{H} 1$ accepted which means there is a significant difference.

\section{RESEARCH RESULTS AND DISCUSSION}

\section{A. Research Results}

1) Description of Research Location

This research was conducted in Medan Johor District. Medan Johor Subdistrict is one of 21 sub-districts located in Medan. It is a residential area, a tourist development area and located in the southern suburbs of Medan which is directly adjacent to Deli Serdang Regency. The total area of \pm 1.696 Ha consists of 6 sub-districts, namely Suka Maju Village, Titi Kuning Village, Kedai Durian Village, Pangkalan Masyhur Village, Johor Building Village, and Kwala Bekala Urban Village.
Figure 2. Map of Medan Johor Sub-district, Source: Expose Kecamatan Medan Johor 2015. Obtained from Medan Johor Sub-district Office on June 2016

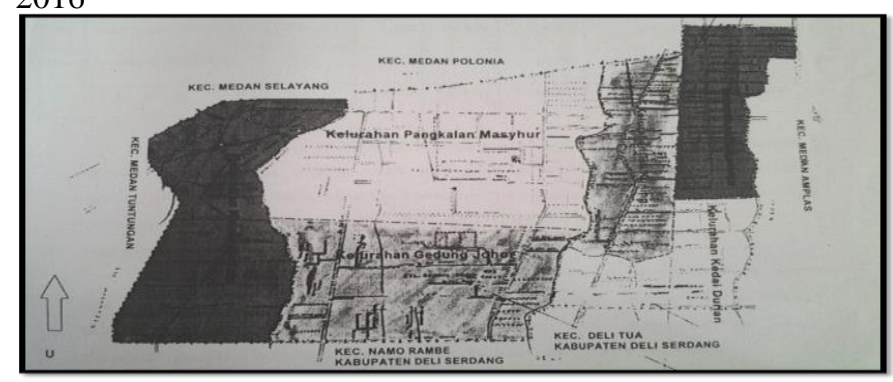

a) Deviation Test Results of Classic Assumption

b) Normality Test Results

The research conducted normality test to residual by analyzing graphs and normality using Kolmogorov-Smirnov and the significance level used was $\alpha=0,05$.

Figure 3. Histogram Normality Test Results Source:Research Results, 2015 (Research Processed Data)

Histogram

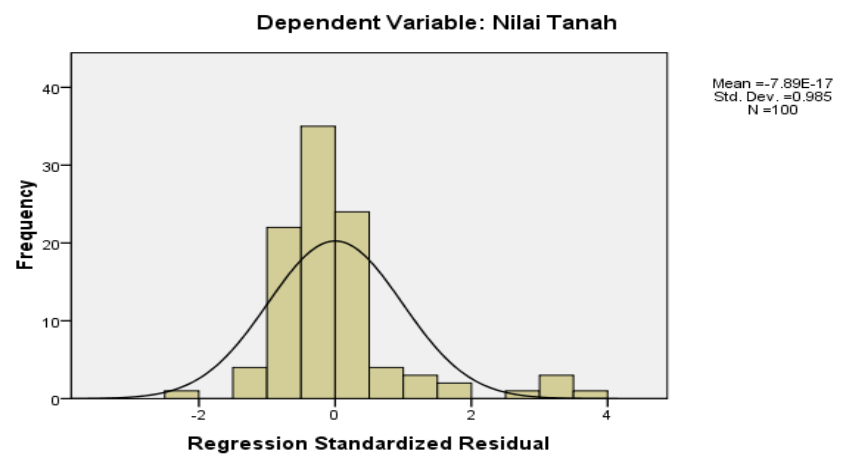

Following is the normality test results of a regression model with graph analysis:

The histogram presents that dependent and standardized residual curve forms a bell-like curve. Therefore, based on the normality test, the regression analysis is feasible to be used although there is a little slope.

Table 1 . The results of the normality test using Kolmogorov-Smirnov

\begin{tabular}{llr}
\hline \multicolumn{1}{c}{ Uraian } & & \multicolumn{2}{c}{ Standardized } \\
& & Residual \\
\hline $\mathrm{N}$ & & 100 \\
Normal Parameters ${ }^{\mathrm{a} \_\mathrm{b}}$ & Mean &, 0000000 \\
& Std. Deviation &, 98984745 \\
Most Extreme & Absolute &, 104 \\
Differences & Positive &, 104 \\
& Negative &,- 083 \\
Kolmogorv-Smirnov Z & & 1,039 \\
Asymp. Sig. (2-tailed) & &, 231 \\
\hline
\end{tabular}

a. Test distribution is Normal.

b. Calculated from data. 
Based on the results of normality test results on the regression model in Table 1 above, it is indicated that the model has met the assumption of normality test because the probability value p.KS $=0.231>0.05$ (Asymp. Sig.).

\section{2) Multicollinearity Test}

In this study, multicollinearity test results are shown in Table 2 below:

Table 2. multicollinearity test results

\begin{tabular}{lll}
\hline \multicolumn{1}{c}{ Model } & Collinierity & Statistics \\
\hline & Tolerance & VIF \\
\hline (Constant) & & \\
Luas Tanah & 0,943 & 1.061 \\
Lebar Jalan & 0,722 & 1.386 \\
Lokasi (Letak) & 0,727 & 1.375 \\
\hline
\end{tabular}

By looking at VIF (Variable in Floating Factor) variable of land area is 1,061 , VIF value of road width is 1,386 , and VIF of location variable is 1,375 . It can be seen that both model structures had a tolerance value higher than 0.10 and VIF was lower than ten so it can be said that the model structure in this study did not experience symptoms of multicollinearity.

\section{3) Heteroscedasticity Test Result}

The following is heteroscedasticity assumption test results of the research model structure:

Figure 4. Scatter Plot Graph

Source: Research result, 2016 (Research Processed Data)

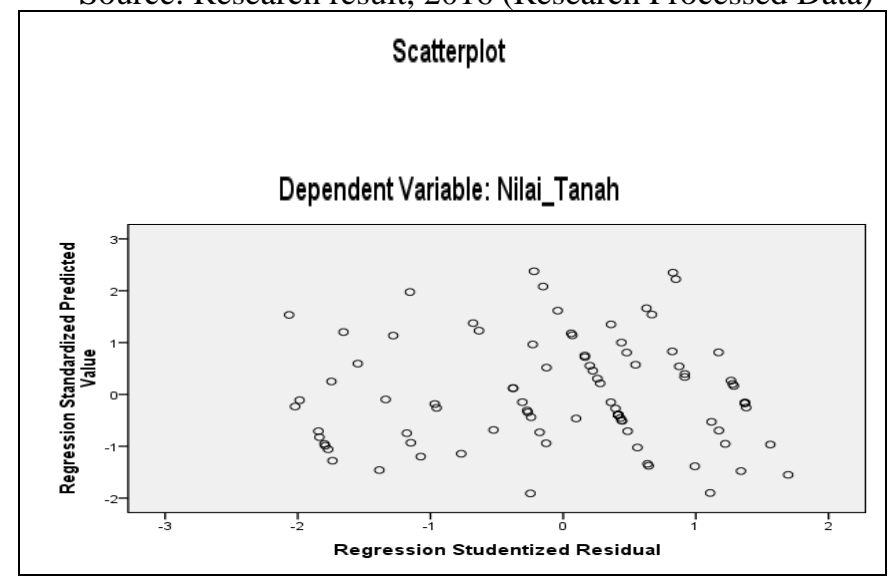

It can be seen from Figure 4 above, that the points spread above and below the number ' 0 ' on the ' $y$ ' axis so that it can be said that the model structure did not experience heteroscedasticity or model structure had homoscedasticity.

Heteroscedasticity test with common used graphic methods is used although it raises the bias since observations between one observer and another observer can lead to differences in perception. Therefore, the use of statistical tests is expected to eliminate the element of such bias. One of the commonly used statistical tests is the Glejser Test. The Glejser test is performed by regressing the independent variables to its residual absolute value (Gujarati, 2004). As a basic understanding, the residual is the difference between the observed value and the predicted value; and absolute is the absolute value.

Table 3. Glejser Test results

\begin{tabular}{|c|c|c|c|c|c|c|}
\hline \multirow[b]{2}{*}{ Madel } & & \multicolumn{2}{|c|}{ Unstandardized Coefficients } & \multirow{2}{*}{$\begin{array}{c}\begin{array}{c}\text { Standardized } \\
\text { Coefficients }\end{array} \\
\text { Beta }\end{array}$} & \multirow[b]{2}{*}{$t$} & \multirow[b]{2}{*}{ Siq. } \\
\hline & & $\mathrm{B}$ & Std. Error & & & \\
\hline \multirow[t]{4}{*}{1} & (Constant) & 128767.573 & 104642.534 & & 1.231 & .221 \\
\hline & Luas_Tanah & -44.179 & 37.909 & -.118 & -1.165 & .247 \\
\hline & Lebar_Jalan & 59557.133 & 24513.382 & .281 & 2.430 & .017 \\
\hline & Lokasi_Letak & -13209.277 & 105484.883 & -.014 & -.125 & .901 \\
\hline
\end{tabular}

Based on the lesser test results in table 3 above, it is indicated that the significance value of land width (X1) is 0,247 , variable of road width (X2) is 0,017 , and dummy location variable (D1) is 0,901 . This proved that 3 (three) variables mentioned above had a significance value higher than 0.05 , meaning that there was no heteroscedasticity on all variables.

4) Hypothesis test result (Goodness of Fit)

Table 4. Coefficient Determination Test Results(R2)

\begin{tabular}{|c|c|c|c|c|}
\hline$\perp^{\text {Mode }}$ & $\mathrm{R}$ & R Square & $\begin{array}{c}\text { Adjusted R } \\
\text { Square }\end{array}$ & $\begin{array}{l}\text { Std. Error of } \\
\text { the Estimate }\end{array}$ \\
\hline 1 & $.613^{2}$ & .376 & .356 & $5.74879 \mathrm{E} 5$ \\
\hline
\end{tabular}

Table 4 demonstrates that the values of Adjusted R2 of the model structure were 0,356 or $35,60 \%$. It indicated that the presentation value of the land area (X1), road width (X2), and dummy variable of location (D1) in the description of Land Value (Y) was $35,60 \%$ and residual $64,40 \%$ which was influenced by other factors which were not mentioned in this research.

Simultaneous Test Results (F-Test) was performed to conclude the value of significance on the influence of independent variables to the dependent variable. F-count value of the regression model for the dependent variable, i.e., Land Value (Y) can be seen from Table 5 below:

Table 5. Simultaneous Test Results

\begin{tabular}{|c|c|c|c|c|c|c|}
\hline \multicolumn{2}{|c|}{ Madel } & $\begin{array}{c}\text { Sum of } \\
\text { Squares }\end{array}$ & df & Mean Square & $\mathrm{F}$ & Sig. \\
\hline \multirow[t]{3}{*}{1} & Regression & $1.910 \mathrm{E} 13$ & 3 & $6.366 \mathrm{E} 12$ & 19.261 & $.000^{2}$ \\
\hline & Residual & $3.173 \mathrm{E} 13$ & 96 & $3.305 \mathrm{E} 11$ & & \\
\hline & Total & $5.082 \mathrm{E} 13$ & 99 & & & \\
\hline
\end{tabular}

The table 5 shows that the influence of land area variable (X1), road width variable (X2), and dummy variable of location (location) (D1) on Land Value (Y) was simultaneously significant since the value of sig.-F $(0,000)$ is smaller than 0,05 . 
Table 6. Partial Test Results (t-Test)

\begin{tabular}{|c|c|c|c|c|c|c|c|c|}
\hline \multirow[b]{2}{*}{ Model } & & \multicolumn{2}{|c|}{ Unstandardized Coefficients } & \multirow{2}{*}{$\begin{array}{c}\begin{array}{c}\text { Standardized } \\
\text { Coefficients }\end{array} \\
\text { Beta }\end{array}$} & \multirow[b]{2}{*}{ t } & \multirow[b]{2}{*}{ Siq. } & \multicolumn{2}{|c|}{ Collinearity Statistics } \\
\hline & & $\mathrm{B}$ & Std. Error & & & & Tolerance & VIF \\
\hline \multirow[t]{4}{*}{1} & (Constant) & 164214.075 & 142199.440 & & 1.155 & .251 & & \\
\hline & Luas Tanah & -107.300 & 51.515 & -.173 & -2.083 & .040 & .943 & 1.061 \\
\hline & Lebar Jalan & 212701.956 & 33311.400 & .606 & 6.385 & .000 & .722 & 1.386 \\
\hline & Lokasi_Letak & 60681.616 & 143344.114 & .040 & .423 & 673 & .727 & 1.375 \\
\hline
\end{tabular}

Table 6 demonstrates that partially land area (X1), road width (X2), and location (D1) did not all have the significant influence on Land Value (Y); it was indicated by the probability (Sig.) of each variable.

An independent variable is said to have the significant influence on dependent variable if its probability value of $t$ count is lower than the significance level used. The significance level used in this research was $5 \%(0,05)$. The form of the regression model of the model structure was as follows:

$$
\mathrm{Y}^{\wedge}=-0,173 \mathrm{X} \_1+0,606 \mathrm{X} \_2+0,040 \mathrm{D} \_1+\mu
$$

Notes: The regression results in Table 5.14 above clearly shows the empirical test results that indicate that the influence of land area (X1) on land value is represented by t-count $2.083<$ t-table $1,661(\alpha=0,05)$ and the probability value (Sig.) was 0,040 which was lower than alpha 5\%. The partial test results of the variables of the land area show that Ho was not rejected, $\mathrm{t}$-table $\leq \mathrm{t}$-count $\leq \mathrm{t}$-table, which meant that land area had the significantly negative influence on land value. The research results rejected the hypothesis stating that "there is a significantly positive influence of land area on land value." It can also be said that Land Area (X1) indirectly influenced Land Value (Y).

Result of empirical test to the influence of Road Width (X2) on land value shows t-count value 6,385> t-table 1,661 and its probability value (Sig) 0.000 below 5\% alpha. The partial test result of road width variable showed that the Ho was rejected. This meant that the number of floors had a significant positive effect on the value of the land. The results of this research accepted the hypothesis that "there is a significantly positive influence of road width on the value of the land." And it can also be said that Road Width (X2) directly had the significant influence on the Land Value Level (Y).

Result of empirical test to the influence of location (D1) on land value shows value of t-count $0,423>\mathrm{t}$-table $1,661(\alpha=$ 0,05 ) and its probability value (Sig.) equal to 0,673 and above alpha $5 \%$. The result of the partial test of dummy variable of location shows that Ho is not rejected, $\mathrm{t}$-table $\leq \mathrm{t}$-count $\leq \mathrm{t}$ table, it means that location did not have any significant influence on land value. The results rejected the hypothesis that "location has a significantly positive influence on the value of land." And it can also be said that Location (D1) directly had insignificant influence on Land Value (Y).

\section{B. Research Result Discussion}

The result of this research showed that the variable of land area $(\mathrm{X} 1)$ had prob. $\mathrm{t}$-statistic 0.040 lower than 0.05 with the $\mathrm{t}$ count value of -2.083 lower than t-table $1.661(\alpha=0.05)$, it can be said that land area indirectly had a significant influence on land value (Y). This is in contrast with the results of the research conducted by previous researchers, i.e., research conducted by Edy Siswanto (2006) in his research stated that land area has a significantly positive influence on land value for the determination of NJOP of land.

Theoretically, it is stated that the measurement used to express land area depends on the place and utility of the land. The land area of certain size and utilization does not significantly influence the value of land, such as the land area for housing purposes. But on larger lands, for example for the utilization of agricultural activities, there is a tendency that larger the land, the higher its value per meter because if the land is too large, it will have more problems in management (Hidayati and Harjanto, 2003).

The result of this research demonstrated that road width (X2) had prob. t-statistic 0.000 lower than 0,05 with t-count value equal to 6,385 higher than t-table $1,661(\alpha=0,05)$, it was concluded that the road width directly had a significant influence to soil value (Y). This was supported by the results of the research conducted by previous researchers i.e. the research conducted by Adrian Sutawijaya (2004) which stated that the width of road had a positive and significant influence on the value of land as the basis of valuation of the sale value of tax objects (NJOP) of the land in Semarang.

The width of the road influenced the value of the land at the research areas because the larger roads would certainly be able to accommodate better vehicular traffic compared to smaller ones. This was also attributed to the adequate accessibility of the land. Khair (2008) stated in his research on the influence of accessibility and the nearest environment in East New Primary Sentra on the price of the surrounding land. This research concluded that the width of the road had a significant influence on the rise in land prices.

The research area, the area of artery road located in the scope of the area of Medan Johor in particular, is a place in which property is used for business activities and trade services both by direct owners and tenants. Building on the side of the road is used for offices and shops. Seeing this condition, the width of the road for each designation should be adjusted to the business involved so that the size of the road width becomes the determining factor to obtain an efficient and effective economic value, in this case, the width of the road is considered as one of the main factors in opening business or economic activity. Medan Johor District is also known as a residential area. Housing, in general, provides road facilities that are wide enough to highlight the impression of luxury or comfort of a residence for the residents. Thus, it is very reasonable if the road width significantly influences the value of the land.

The research results demonstrated that location (D1) had a prob. t-statistics higher than 0.673 higher than 0.05 with a tcount value of 0.423 is greater than t-table $1.661(\alpha=0.05)$, it 
can be said that location directly did not have any significant influence on the value of land (Y). This is in contrast with the results of research conducted by previous researchers, i.e., the research conducted by Adrian Sutawijaya (2004) which states that location had a significantly positive influence on the value of land for the determination of NJOP of land. Different research conducted by Muslims (2008) stated that location, i.e., distance to Mataram City CBD and front road width as well as physical factor, i.e., rented floor area and effective building age indicated a significant influence on the variation of land value.

Hans and Basuki (2000) state that distance to the commercial center has a significantly negative influence on the value of land. This is in line with the theory proposed by Von Thunen who says that the price of land is based on the distance metric to the center of socio-economic activities. One thing that must be perceived from Von Thunen's theory is that the distance to CBD is the distance of the lands on the side of the road to access $\mathrm{CBD}$, not the absolute distance to $\mathrm{CBD}$ on the map or the distance drawn in a straight line to CBD.

Hidayati and Harjanto (2003) [11] added by stating that location can be considered as the most powerful factor that influences the value of property. Two properties with the same physical, but different locations will have different values. However, all data in this research are the result of mass valuations, and the determination of value is only done by using the Zone to the location of the tax object in general, not the accurate location of a tax object, it is natural that the value obtained is not the actual one and the location does not influence the land value for the tax object.

\section{CONCLUSION AND SUGGESTION}

\section{A. Conclusion}

Land Area had the negative and significant influence on land value. It means that land area indirectly has the significant influence on the land value to determine the land NJOP un Medan Johor Sub district, Medan.

Road width had positive and significant and positive influence on land value. It indicated that land area directly had the significant influence on land value to determine the land NJOP in Medan Johor Subdistrict, Medan.

Location did not have significant influence on land value in determining the land NJOP in Medan Johor Subdistrict, Medan

\section{B. Suggestion}

It is suggested that the government, Medan Regional Revenue Agency, in particular, improve and develop property valuation system; if possible, the valuation is made individually instead of communally like what has been done so far. Therefore market data that is referred to by the analysis of NIR (Average Indicating Rate) as the ground to determine NJOP will be more accurate.

\section{REFERENCES}

[1] Wahyudi H, Eddhi. 2012. SISMIOP : Sistem Pengelolaan Data PBB P2. WordPress.com, Jakarta.

[2] Harian Seputar Indonesia. 2009. Sistem Manajemen dan Informasi Objek Pajak (SISMIOP) yang diterapkan selama ini dianggap sudah kadaluarsa. Berita Online, Jakarta

[3] Darwin, MBP., 2013. Pajak Bumi Dan Bangunan Dalam Tataran Praktis. Mitra Wacana Media, Jakarta.

[4] Widodo, Pamuji. 2011. Analisis Kemampuan dan Efektifitas Keuangan Daerah Empat Kabupaten Di Pulau Madura Dalam Era Otonomi Daerah. Tesis. Fakultas Ekonomi Universitas Jember, Jawa Timur.

[5] Komite Penyusun SPI. 2015. Kode Etik Penilaian Indonesia \& Standar Penilaian Indonesia Edisi VI, MAPPI, Jakarta.

[6] Siswanto, Edy, 2007. Analisis Pengaruh Jarak, Lebar Jalan dan Luas Tanah untuk Penentuan NJOP Bumi (Studi Kasus di Kelurahan Sukagilih Kota Bandung). Insitut Teknologi Bandung, Bandung.

[7] Fajarhayu Tri, 2014.Analisis Tingkat Akurasi Dinas Pendapatan Daerah dalam Mementukan Nilai Jual Objek Pajak Bumi dengan Menggunakan Metode Assesment Sales Ratio (Studi Kasus di Kecamatan Sumberrejo Kabupaten Bantul Bojonegoro tahun 2014).

[8] Sugiyono. 2012. Metode Penelitian Kuantitatif, Kualitatif dan R\&D. CV. Alfabeta, Bandung.

[9] Fachruddin, Khaira Amalia \& Juli Meliza. 2014. Metode Penelitian. USU PRESS, Medan.

[10] Ghozali, Imam. 2006. Ekonometrika Teori, Konsep dan Aplikasi Dengan SPSS 17. Cetakan Kedua. Universitas Diponegoro, Semarang.

[11] Hidayati, Wahyu dan Budi Harjanto. 2003. Konsep Dasar Penilaian Properti. BPFE, Yogyakarta.

[12] Arikunto, Suharsimi. 2014. Prosedur Penelitian Suatu Pendekatan Praktek. PT. Rineka Cipta, Jakarta.

[13] Aries Sugiarto, Bambang. 2006. Analisis Valuation Sales Ratio Antara NJOP Tanah Dengan Harga Tanah di Kabupaten Karanganyar. Jurnal Survey dan Penilaian Properti. Vol.50.

[14] Amelia, Tri Restu Febriyanti. 2007. Studi Pelaksanaan SISMIOP (Sistem Manajemen Informasi Objek Pajak) di Kantor Pelayanan Pajak Bumi dan Bangunan Pamekasan. Jurnal. Universitas Brawijaya, Pamekasan.

[15] Aprianty, Rika Dwi dan Robert Lambey. 2016. Evaluasi Sistem Manajemen Informasi Objek Pajak (SISMIOP) Terhadap Penerimaan Pajak Bumi dan Bangunan (Studi Kasus di Kota Bitung). Universitas Sam Ratulangi, Manado.

[16] Asy'ari, Muhammad. 2015. Pengaruh Aplikasi Sistem Manajemen Informasi Objek Pajak (SISMIOP) Terhadap Tingkat Kualitas Pelayanan Pajak Bumi dan Bangunan Perdesaan dan Perkotaan (PBB P2) (Studi pada Dinas Pendapatan, Pengelolaan Keuangan dan Aset Daerah Kabupaten Situbondo). Jurnal Mahasiswa Perpajakan. Universitas Brawijaya, Malang.

[17] Badan Pusat Statistik Kota Medan. 2010. HasilSensus Penduduk 2010, Data Anggregat Per-Kecamatan Kota Medan.

[18] Budi K, Rizki, Sutomo Kahar, dan Sawitri Subiyanto. 2014. Pembuatan Peta Zona Nilai Tanah Dengan Pendekatan Penilaian Massal Untuk Meningkatkan Potensi PAD (Pendapatan Asli Daerah) Khususnya PBB dan BPHTB Studi Kasus Kecamatan Banjarsari Kota Surakarta. Jurnal Geodesi Undip. Universitas Diponegoro, Semarang.

[19] Hartoyo, Harry dan Untung Supardi. 2010. Membedah Pengelolaan Administrasi PBB \& BPHTB. Mitra Wacana Media, Jakarta.

[20] Mursito, Bambang. 2014. Penilaian Jual Objek Pajak (NJOP) Yang Berkeadilan Dengan Metode Valuation Sales Ratio. Jurnal Fakultas Ekonomi dan Bisnis. Universitas Kristen Satya Wacana, Surakarta.

[21] Niapele Sarifa, 2014, Analisis Faktor Faktor yang Berpengaruh Terhadap Implementasi Pajak Bumi dan Bangunan di Kecmatan Sirimau Kota Ambon, STIA ALAZKA Ambon.

[22] Novie, Amelia Sandra. 2010. Analisis Tingkat Akurasi Penetapan NJOP Terhadap Nilai Pasar Dengan Metode Valuation Sales Ratio, Stiudi Kasus di Kecamatan Kelapa Gading Kotamadya Jakarta Utara). Institut Bisnis dan Informatika Indonesia, Jakarta. 
[23] Novianti, Pratiwi. 2014. Penerapan Sistem Manajemen Informasi Objek Pajak (SISMIOP) Sebagai Sarana Peningkatan Pelayanan dan Penerimaan Pajak Bumi dan Bangunan di Kota Makassar. Jurnal Ekonomi. Universitas Hasanuddin, Makassar.

[24] Paat, Elriza. 2012. Tingkat Akurasi Penetapan NJOP Bumi Terhadap Nilai Pasar Dengan Metode Valuation Sales Ratio di Kecamatan Sario Kota Manado. Jurnal Fakultas Ekonomi. Universitas Sam Ratulangi, Manado.

[25] Pahala Siahaan, Marihot. 2009. Pajak Bumi \& Bangunan di Indonesia (Teori dan Praktik. Graha Ilmu, Yogyakarta.

[26] Siswanto, Edy, 2007. Analisis Pengaruh Jarak, Lebar Jalan dan Luas Tanah untuk Penentuan NJOP Bumi (Studi Kasus di Kelurahan Sukagilih Kota Bandung). Insitut Teknologi Bandung, Bandung.

[27] Sukandarrumidi, Haryanto, 2008. Dasar-Dasar Penulisan Proposal Penelitian. Gadjah Mada University Press, Yogyakarta.

[28] Sunyoto Danang. 2013.Analisis Data Ekonomi dengan Menggunakan SPSS. PT. Indeks, Jakarta.

[29] Suryawati, Rindah Febriana, Gita Arasy Harwida, dan Suryadi. 2010. Analisa Penetapan NJOP (Nilai Jual Objek Pajak) Pajak Bumi Terhadap Nilai Pasar Dengan Metode Valuation Sales Ratio. Jurnal Akuntansi. Fakultas Ekonomi Universitas Trunojoyo, Madura.

[30] Sutarwija, Adrian. Analisis Faktor Faktor yang Mempengaruhi Nilai Tanah sebagai Dasar Penilaian Nilai Jual Objek Pajak (NJOP) PBB di Kota Semarang, Jurnal Ekonomi Pembangunan.

[31] Syaharuddin. 2014. Akurasi Nilai Jual Objek Pajak (NJOP) Menara Seluler Sebagai Dasar Pengenaan Pajak Bumi dan Bangunan (PBB) Terhadap Nilai Pasar. Tesis S2. Fakultas Ekonomi dan Bisnis Universitas Gadjah Mada, Yogyakarta.

[32] The International Association of Assessing Officers. 1978. Standart On Ratio Studies. The International Association of Assessing Officers, Kansas.

[33] Widodo, Pamuji. 2011. Analisis Kemampuan dan Efektifitas Keuangan Daerah Empat Kabupaten Di Pulau Madura Dalam Era Otonomi Daerah. Tesis. Fakultas Ekonomi Universitas Jember, Jawa Timur.

[34] Winarno, Budi. 2009. Undang-Undang No. 28 Tahun 2009 Tentang Pajak Daerah dan Retribusi Daerah, Dirjen Pajak, Jakarta. 